new laboratory at Reading until his retirement in 1956.

During his thirty-five years in the agricultural advisory service, Buddin somehow made time to carry through and publish a not inconsiderable volume of fundamental research on fungal diseases of crops and ornamental plants, in addition to the more ad hoc investigations on disease control that arose out of his work as an adviser. Most of his more important work was published in collaboration with Miss E. M. Wakefield. Best known is their joint work on the violet root rot disease, in the course of which they established that Helicobasidium purpureum was the perfect state of the pathogen, until then known only as a sterile mycelium (Rhizoctonia crocorum). Although this discovery attracted widespread attention, equal credit is due to Buddin and Wakefield for their preliminary study of the biology of $R$. crocorum in culture. They were among the first mycologists to isolate this fungus in pure cultureat that time a considerable technical feat. Twenty years later, when I followed in their footsteps, I was able to confirm their observations and to admire the thoroughness and mycological finesse of their work.

Gifted as he was in his capacity as a research worker, yet as an agricultural adviser Buddin had, in my opinion, no equal. He combined an immense zest for his job with an uncanny knack of being able to enter into the minds of farmer and research worker simultaneously, so that he was the ideal interpreter of one to the other. Above all this, he had an extraordinary flair for seeing how research findings could be put into practice, though fow people can have realized just how great was his contribution in this respect, because Buddin was a most generous man and seemed to care little about recognition for himself. Many young men besides me had this generous help from him, were made to foel that their research work was worth doirig and were taught by example rather than by precept that one had to become an expert in general crop husbandry before one could become useful as a plant pathologist. A large part of Buddin's success with farmers was due to his kindly and never-flagging interest in the affairs of other people and to a most retentive memory. In the houses of his hosts, he was able to ask the most direct and personal questions without causing the slightest offence; a few years later, this information would be deployed to great effect in inquiries about the well-being of the family concerned.

Buddin's outstanding services to science and agriculture were widely recognized. He was elected an honorary member of the British Mycological Society in 1954 and of the Association of Applied Biologists in 1959 , and was the first British biologist to hold both these distinctions. His association with the British Mycological Society was a particularly close one; at one time or another he held most of the offices of the Society, though he characteristicully refused to be nominated for the presidency. His final service to the Society was as troasurer during 1947-61, during which time the Council received much wise advice, and the most tedious business was invariably enlivened by Buddin's pithy comments. Wit and philosopher though he was, it was perhaps Buddin's infectious enjoyment of his life and work that most endeared him to his friends and helped them to do the same. To have been helped by, and to have exjoyed the friendship of, such a man will be the treasured recollection of many of us.

S. D. GarretT

\section{Prof. V. N. Beklemishev}

Prow. Vladimir Nikolaievitch Beklemishev, head of the Division of Entomology of the Martsinovsky Institute of Medical Parasitology and Tropical Medicine of the U.S.S.R. Ministry of Health, member of the U.S.S.R. Academy of Medical Sciences, died in Moscow on September 4 at the age of seventytwo years.

Prof. Beklemishev's death will leave in the field of medical entomology a gap that will not be easy to fill. His contribution to basic science was immense, linked with his interest in applied research and particularly related to problems of public health and to malaria eradication. Thirty years ago, while still on the staff of the University of Perm, Prof. Beklemishev became interested in the biology of impounded waters giving rise to large-scale breeding of Anopheles. This work led to the study of epidemiology of malaria, to which Prof. Beklemishev had devoted most of his work since 1932, when he was appointed head of the Entomology Division of the Malaria Institute in Moscow (now the Martsinovsky Institute of Medical Parasitology and Tropical Medicine).

In his new post, Prof. Beklemishev devoted all his knowledge, energy and experience to the organization of country-wide control of malaria, tick encephalitis and other arthropod-borne diseases.

Beklemishev's outstanding book on the comparative anatomy of invertebrates, first published in 1944, saw a second edition in 1952 and was translated into many languages. His book on the ecology of $A$. maculipennis, published in 1948 , was equally suc. cessful. Beklemishev's main achievement was the thorough planning and organization of collective research on the bionomics of arthropod vectors of communicable diseases in the U.S.S.R. One of the results of this work was a recent book on seasonal changes in the biology of $A$. maculipennis over the whole vast territory of the U.S.S.R.- $a$ unique achievement in the field of entomological science. He also wrote a foreword to the monograph on age-grouping methods in Diptera of medical importance (prepared by one of his pupils, Dr. T. S. Detinova), which was recently published by the World Health Organization.

Beklemishev greatly increased our understanding of ecological and phenological factors in the distribution of malaria and introduced new notions of 'landscape malariology' as a basis for planning malaria control and eradication. The study of the physiology of malaria vectors led Beklemishev and his collaborators to the introduction of new methods of age-grading of female Anopheles. The importance of this in the epidemiological follow-up of malaria eradication was fully realized in the U.S.S.R. and is now increasingly appreciated in other parts of the world. The age-grading methods developed by the school created by Beklemishev are now being used for the study of the biology of house flies, tsetse flies, black flies and midges in other countries. Beklemishev's wide interests and keen intellect contributed greatly to the study of population biology of arthropods, to the study of the evaluation of parasitism in blood-sucking vectors of human and animal diseases, to the development of nosogeography of communicable diseases and to the analysis of general and specific aspects of natural foci of infection.

He was the author of a series of handbooks on medical ontomology and taught this subject to thousands of students at the Lomonosov University, at the Martsinovsky Institute and at the Central Postgraduate Medical School in Moscow. Beklemi- 
shev's brilliant teaching always emphasized the link between basic research and practical problems of public health.

The highest U.S.S.R. State prize for scientific work was given to Beklemishev twice: the first time for his study of comparative anatomy of invertebrates; the socond time for his entomological work in the field of malaria eradication in the U.S.S.R., so ably led by Prof. Sergiev, his friend and colleague. He was a consultant on entomology and vector control to the Ministry of Health, U.S.S.R., and co-editor of the journal Meditsinskaya Parasitologia i Parazitarnye Bolezni. $\mathrm{He}$ was also a member of the Expert
Advisory Panel on Malaria of the World Health Organization.

Beklemishev had an immense fund of knowledge in the field of entomology, hydrobiology, geomorphology and biostatistics and was always ready and eager to place his experience at the disposal of those who consulted him. His lectures were a model of clarity in presentation and often enlivened by delightful humorous asides. His main outside interest was the history of art and he was a keen student of painting and sculpture. $\mathrm{He}$ was a kind and a wise man and his absence will be sadly felt by his many friends and admirers everywhere.
L. J. BruCE-CHWATT

\section{NEWS and VIEWS}

\section{The Royal Society of Edinburgh}

THE following have been elected officers and members of Council of the Royal Society of Edinburgh for the Session 1962-63: President, Prof. E. L. Hirst; VicePresidents, Dr. A. W. Greenwood, Prof. R. A. Rankin, Dr. C. E. Lucas, Prof. J. A. Macdonald, Dr. H. R. Fletcher and Prof. G. L. Montgomery; General Secretary, Prof. Norman Feather; Secretaries to ordinary meetings, Dr. Mowbray Ritchie and Prof. A. E. Ritchie; Treasurer, Dr. J. R. Peddie; Curator of Library and Museum, Dr. R. Schlapp; Councillors, Prof. J. H. Burnett, Prof. C. F. Davidson, Prof. D. C. Pack, Dr. A. B. Stewart, Prof. Jack Allen, Dr. S. C. Curran, Dr. G. H. Mitchell, Dr. Magnus Pyke, Prof. R. B. Fisher, The Rev. Dr. A. M. Gillespie, Prof. A. Robertson and Prof. P. A. Sweet.

The Smithsonian Institution, Washington: New Appointments

ON Oetober 31, Dr. Remington Kellogg retired from the posts of assistant secretary of the Smithsonian Institution and director of the United States National Museum, Washington, after forty-two years in Government service. Dr. Kellogg, one of America's leading biologists, will continue his research at the Smithsonian as an honorary research associate of the Institution.

Dr. Albert C. Smith, who has been director of the Smithsonian's Museum of Natural History since 1958, becomes an assistant secretary of the Institution. Dr. Smith, well known for his work in phanerogamic botany, is a native of Springfield, Mass. He received his Ph.D. in 1933 from Columbia University. Thereafter he was associated with the New York Botanical Garden, the Arnold Arboretum of Harvard University, and the National Herbarium of the Smithsonian. In addition to study and research in England, France, Switzerland, Germany, Holland and the Scandinavian countries, he has participated in several botanical expeditions to Colombia, Peru, Brazil, Fiji, British Guiana, and the Lesser Antilles.

Mr. Frank A. Taylor has been appointed director of the United States National Museum (composed of two Smithsonian museums-the Museum of Natural History and the Museum of History and Technology). He has served in various euratorial and administrative positions at the Smithsonian Institution since 1922. Since 1958 he has been director of the Museum of History and Technology, the new building of which is now nearing completion on Constitution Avenue. He will continue to hold the latter position in addition to his new post. Mr. Taylor is a native of Washington, D.C. $\mathrm{H} \theta$ holds an engineering degree from the Massachusetts Institute of Technology and a degree of law from Georgetown University.

Dr. T. Dale Stewart has been appointed director of the Museum of Natural History. Dr. Stewart's service at the Smithsonian dates from 1927. In 1942 he succe日ded the late Dr. Aleš Hrdlička as curator of the Museum's Division of Physical Anthropology, a position he held until early 1961, when he was made head eurator of the Department of Anthropology. He will also continue in the latter position. Dr. Stewart, a native Pennsylvanian, is a graduate of George Washington University and holds an M.D. degree from Johns Hopkins Medical School. His research work has been principally concerned with bone structure and pathology, dental caries, anthropometry of Eskimos and Indians, and cranial deformities. $\mathrm{He}$ is frequently called on by the Federal Bureau of Investigation as an expert on the identification of skeletal remains. He is the author of many scientific papers, has been on numerous scientific expeditions in many parts of the world, and is the recipient of many professional honours, including the Viking Medal and award for outstanding anthropological research. He was recently elected to membership in the National Academy of Sciences.

\section{Botany at the University of the Witwatersrand: Prof. E. R. Roux}

Dr. E. R. Roux, senior lecturer in the Department of Botany at the University of the Witwatersrand, has been appointed to the chair of botany in succession to Prof. N. P. Badenhuizen, who resigned some time ago to go to Canada. After matriculating at Jeppe High School, Dr. Roux went to the University of the Witwatersrand. He obtained his M.Sc. degre $\theta$ in 1926 and was then appointed junior lecturer in the Department of Botany. Soon afterwards he was awarded a scholarship of the Exhibition of 1851 and went to the University of Cambridge, where he obtained his Ph.D. degree for a thesis on plant physiology in 1929. On his return to South Africa he was employed for a time in the Government Low Temperature Research Laboratory. Later, as the holder of a Carnegie grant and the Thomas Smartt scholarship, he conducted investigations on fruit storage problems in the Department of Chemistry at the University of Cape Town. During the Second World War he conducted investigations on fish oils and various marine biology problems, and played an 